\title{
5-Aminolevulinate Synthase, Nonspecific, Mitochondrial
}

National Cancer Institute

\section{Source}

National Cancer Institute. 5-Aminolevulinate Synthase, Nonspecific, Mitochondrial. NCI

Thesaurus. Code C111874.

5-aminolevulinate synthase, nonspecific, mitochondrial (640 aa, $71 \mathrm{kDa}$ ) is encoded by the human ALAS1 gene. This protein plays a role in both protoporphyrin biosynthesis and lipid metabolism. 